\title{
$N$-アルキル置換アクリルアミド系ポリマーによるアニオン性ポリスチレン ラテックスの分散安定化
}

\author{
浅田 啓介*1・城戸 淳二*1 ・ 倉本 憲幸*1 ・長井 勝利*1
}

（受付 1995 年 4 月 6 日・雷査終了 1995 年 6 月 26 日）

\begin{abstract}
要 旨 $N$-アルキル置換アクリルアミド系ポリマーのポリスチレン (PS) ラテックスに対する分散安定化効果を 電解質の臨界凝集滣度から評価し，ポリマーの特性との関係について検討した。 アクリルアミド系ポリマーは親水 性の高いポリジメチルアクリルアミドであ水中でのPS ラテックスの電解質に対する分散安定化効果を示した。 ま た, 㻋水性の高いモノマー単位を含有するポリマーほど高い分散安定化効果を示す傾向がみられた. 分散安定性に 対するポリマー濃度依存性はポリマー濃度の增加に伴い安定化効果が高くなった．分散安定化効果に対するポリ マー港度依存性はホモポリマーよりあ眯水性のコモノマー単位を含有するコポリマーの方が大きいことが分かっ た. また, 分散安定化効果がポリマーの䝭和吸着量と関係があることが認められた.
\end{abstract}

\section{1 緒言}

近年, 環境問題からインキ, 接着剤, 塗料などの分野 では水性化が進められているが，水への分散質粒子の分 散安定化が重要な課題である．分散剤として低分子の界 面活性剤を用いた場合には吸着性や保護作用が低いこと から，せん断安定性や分散安定性に問題があり，また起 泡による問題にす遭遇する場合がある. 一方，高分子の 界面活性剂は吸着性が高く、吸着した高分子鎖のコン フォメーションの多様性に加え, 立体的保護作用によっ て高い分散安定化効果を示すことが知られているが1), より高い分散安定化作用を発現する高分子界面活性剂の 開発は重要な課題となっている．高分子界面活性剤の分 散剂としての評価はこれまで両性アクリル樹脂を用いた 顔料分散に関する検討 ${ }^{2), 3)}$ や疎水修飾したポリアクリル 酸によるカーボンブラック，二酸化チタンの水への分散 安定化に関する検討4).5)などが行われてきている。 また ポリスチレン (PS) ラテックスに対するポリマーの吸着 と疑集，分散安定化効果についてもいくつかの報告があ る6) 16). しかし，これまでポリマーの構造，親疎水性， 水溶液中でのポリマーの界面活性能, 溶存状態と吸着特 性および分散安定化効果との関係についてまだ十分に検 討されてきていない.

$N$-アルキル置換アクリルアミド系ポリマーはそのモ ノマー単位が親水性基としてのアミド基と疎水性基とし てのアルキル基からなりアルキル基の炭素数を変えるこ とにより, 親水性と疎水性の調節が可能である. また,

*1 山形大学工学部物質工学科（\$992 山形県米沢市城南 4-316)
親水性モノマーと疎水性モノマーとのコポリマーの合成 あ容易である.このような構造要素を持つ $N$-アルキル 置換アクリルアミド系のホモポリマーおよびランダムコ ポリマーは非イオン性高分子界面活性剤としての特性を 持つことが期待できる. しかしながら，これまでアクリ ルアミド系ポリマーに関する検討はPS ラテックスに対 するポリアクリルアミドの凝集効果 ${ }^{22}$ やポリイソプロ ピルアクリルアミド (PIPA) によるアエロジルへの吸着

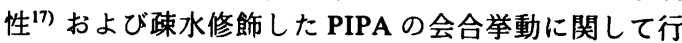
われている(18) 20) のみであり，ポリマーの界面化学的特 性, 吸着特性, 分散機能などに関する検討はなされてい ない。

我々はこれまでモノマー単位のアルキル鎖の長さと含 有量の異なる $N$-アルキル置換アクリルアミド系ポリ マーおよびコポリマーを合成し，ポリマーの親疎水性， 界面活性能および水溶液中での溶存状態と水系での PS ラテックスに対するポリマーの吸着特性との関係につい て検討してきた. そして, PSラテックスへのポリマー の吸着が主に疎水相互作用によるもので，ポリマーの水 中での溶存状態が吸着に影響することを見いだしてき た21). また, 本研究でポリマーのキャラクタリゼーショ ンを行ったところ, ポリマーの親疎水性に関係するポリ マー水溶液の量り点は, 電解質の影響を受けることが分 かった. そこでPSラテックスへのポリマーの吸着に対 しても電解質が影響することが考えられるので, 㟟り点 および吸着に及ぼす電解質の添加効果について検討し た. これらの結果と $N$-アルキル置換アクリルアミド系 ポリマーを吸着したPSラテックスに対する臭化ナトリ ウム, 臭化マグネシウム, 臭化アルミニウムの臨界凝集 濃度 (cfc) から, ポリマーの吸着特性と分散安定化効果 
の関係について考察した.

\section{2 実酸方法}

\section{1 武料}

$N$-アクリロイルピロリジン（APR: 三井東圧化学 (株)), N.N-ジメチルアクリルアミド (DMA: 東京化成 工業(株)), スチレン (ST: 和光純薬工業(株)) はそれ ぞれ脱水後, 減圧蒸留により精製した. $N$-イソプロピ ルアクリルアミド（IPA:（株)興人）はベンゼンとn-へ キサンの混合溶媒 (1:9) から再結晶して精製した。

$N-n$-ヘキシルアクリルアミド (NHA), $N$-n-オクチル アクリルアミド (NOA), N-nードデシルアクリルアミド (NDA) はアクリル酸クロリドと対応するアミンとの反 応により合成した．NHA と NDA はアセトンから， NOA はベンゼンから再結晶を繰り返して精製した。精 製物は IR, 'H NMR, HPLC を用いて構造および純度を 確認した。

水はイオン交換水を蒸留して使用した。 その他の有機 溶媒は蒸留精製したものを使用した。

ポリエチレンオキサイト（PEO: 和光純薬工業(株)), ポリ $\boldsymbol{N}$-ビニルピロリドン (PVP: 半井化学薬品(株)) は 市販品を再沈精製して使用した。

臭化ナトリウム $(\mathrm{NaBr}$ : 試薬特級, 和光純薬工業 (株)), 臭化マグネシゥム・六水和物 $\left(\mathrm{MgBr}_{2} \cdot 6 \mathrm{H}_{2} \mathrm{O}\right.$ : 99.9\%, 和光純楽工業(株)), 臭化アルミニゥム・六水 和物 $\left(\mathrm{AlBr}_{3} \cdot 6 \mathrm{H}_{2} \mathrm{O}\right.$ : 関東化学(株)) は市販品をそのま ま使用した。

2,2'-アソビスイソブチロニトリル (AIBN) は市販品を 再結晶して使用した. 過硫酸カリウム (KPS) は市販品 をそのまま使用した。

ポリマーは開始霍に AIBNを用い,ジオキサン中, 室素察囲気下 $60^{\circ} \mathrm{C}$ での重合により合成した。コポリ マーの組成は 'H NMR を用いて決定した.

ポリスチレン (PS) ラテックスは水溶性開始㓮として 過硫酸カリウム (KPS) を用いてソープフリー乳化重合 法により合成した. 得られた PS ラテックスは遠心分離 とデカンテーションを繰り返して精製した。精製した PS ラテックス粒子の粒径は走查型電子顕微鏡 (SEM: Hitachi S-415 型）写真により決定した. 精製したPSラ テックスの粒径は $0.78 \mu \mathrm{m}$, 標準偏差は $0.02 \mu \mathrm{m}$ であ り, 界面電位は $-17.5 \mathrm{mV}$ であった。

\section{2 测定}

界面電位 ( $\zeta$-電位)： $1 \times 10^{-3} \mathrm{~mol} / \mathrm{L}$ の $\mathrm{KCl}$ 水溶液で 約 $1 \times 10^{-7}$ wt\% の渃度の PS ラテックス溶液を調製し, $\zeta$-電位測定装置（三田村理研工業(株)製モデル 5-17）を 使用し，影微鏡法による電気泳動の測定から $\zeta$-電位を決 定した.

晨り点 (C.P.): $0.1 \mathrm{~g} / \mathrm{dL}$ に調節したポリマー水溶液を
UV-VIS 分光光度計 (Shimadzu UV-210A) を用いて $0.1^{\circ} \mathrm{C} / \mathrm{min}$ で昇温したときの $500 \mathrm{~nm}$ の波長の透過率の 最大値と最小值の中間値を示す温度を篹り点とした。

吸着量：ポリマー水溶液 $\left(0.1 \times 10^{-2} \sim 7.6 \times 10^{-2} \mathrm{~g} /\right.$ dL) を用いて $0.5 \mathrm{wt} \%$ の濃度の PS ラテックス溶液を調 製し， $25^{\circ} \mathrm{C}$ で 20 時間振とうした. 振とう後ラテックス 溶液を $0.2 \mu \mathrm{m}$ の孔径のメンブランフィルターでろ過し た. 万液中のポリマー濃度を UV-VIS 分光光度計 (Shimadzu MPS-2000) を用いて, $200 \mathrm{~nm}$ の吸光度から検量 線を用いて決定し, ポリマー溶液の初期浱度の差から吸 着量を算出した。

表面張力: ポリマー水溶液の表面張力は Wilhelmy 式 表面張力計（協和界面化学(株)製 CBVP A-3) で白金ブ レートを用いて $25^{\circ} \mathrm{C}$ で測定した。

ポリマー水溶液中でのピレンの蛍光強度比 $\left(I_{1} / I_{3}\right): 3$ $\times 10^{-7} \mathrm{~mol} / \mathrm{L}$ の濃度のピレンの水溶液を用いて $0.1 \mathrm{~g} /$ $\mathrm{dL}$ のポリマー水溶液を調製し, その水溶液の励起波長 $340 \mathrm{~nm}$ での蛍光スペクトルを分光蛍光光度計 (Hitachi

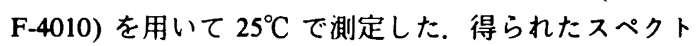
ルより $374 \mathrm{~nm}$ のピーク 1 と $384.5 \mathrm{~nm}$ のピーク 3 の強度 比 $I_{1} / I_{3}$ を求めた.

臨界凝集浱度 (cfc): cfc は Long らの方法22)により求 めた. 所定濃度の PS ラテックス溶液にポリマーを添加 後, $25^{\circ} \mathrm{C}$ で 20 時間振とうし, ポリマーを吸着させた。 そして, このラテックス溶液に電解質 $\left(\mathrm{NaBr}, \mathrm{MgBr}_{2}\right.$, $\left.\mathrm{AlBr}_{3}\right)$ を所定量添加した. $25^{\circ} \mathrm{C} て ゙ 20$ 時間静置後の凝集 状態を UV-VIS 分光光度計を用いて $400 \sim 600 \mathrm{~nm}$ の吸 光度 $(A)$ の対数と波長 $(\lambda)$ の対数曲線の勾配である $n$ 值 $(=\mathrm{d} \log A / \mathrm{d} \log \lambda)$ から求めた. 電解質湦度に対す る $n$ 值の変化から PS ラテックスの臨界凝集浱度 $(\mathrm{cfc})$ を求めた.

\section{3 結果と考察}

3.1 ポリマーの水溶液の特性とポリスチレンラテッ クスへの吸榙特性

Table 1 には本研究で用いたポリマー水溶液の悬り 点, 表面張力, ピレンの蛍光強度比 $\left(I_{1} / I_{3}\right.$ 值) を示し た. $I_{1} / I_{3}$ 值は媒体中の極性によって変化し，ピレンが 極性の高い溶媒中に存在すると高い值（水中では 1.81） を示し, 極性の低下に伴いその值が減少する. そして, 界面活性剂が形成するミセル内に可溶化させた場合には 1.12 となる ${ }^{18)}$. また, $I_{1} / I_{3}$ 值はポリマーの水溶液では その溶存形態とも関連性がある. ポリマーが柾水ドメイ ンを形成する場合には，ピレンがそのドメインに可溶化 され， $I_{1} / I_{3}$ 値が低くなる ${ }^{18)}$ 20). 表面張力は界面活性 能, 而り点はポリマーの親水性と疎水性の割合と関連性 があり，疎水性が高いポリマーは低い量り点を示す。ホ モポリマーで比較すると PDMA は $0^{\circ} \mathrm{C}$ から $100^{\circ} \mathrm{C}$ の範 
N-アルキル置換アクリルアミド系ポリマーによるアニオン性ポリスチレンラテックスの分散安定化

Table 1. Characteristics of poly $(N$-alkylsubstituted acrylamide $\left.) \mathrm{s}^{\mathrm{a}}\right)$

\begin{tabular}{|c|c|c|c|c|c|}
\hline $\begin{array}{c}\text { Code } \\
\text { no. }\end{array}$ & $\begin{array}{c}\text { Polymer } \\
\mathbf{P}\left(\mathbf{M}_{1}-\text { co- } \mathbf{M}_{2}\right)\end{array}$ & $\begin{array}{c}\text { Composition } \\
\text { of } \mathbf{M}_{2}^{\text {b) }} \\
(\mathrm{mol} \mathrm{\%})\end{array}$ & $\begin{array}{l}\text { Cloud } \\
\text { point }{ }^{\mathrm{c}} \\
\left({ }^{\circ} \mathrm{C}\right)\end{array}$ & $\begin{array}{l}\text { Surface } \\
\left.\text { tension }^{d}\right) \\
(\mathrm{mN} / \mathrm{m})\end{array}$ & $I_{1} / I_{3}{ }^{\mathrm{e})}$ \\
\hline \multicolumn{6}{|c|}{ (Homopolymer) } \\
\hline A- 1 & PDMA & 0 & $>100$ & 62.8 & 1.72 \\
\hline A- 2 & PAPR & 0 & 53.0 & 58.5 & 1.72 \\
\hline $\begin{array}{c}\text { A- } 3 \\
\text { (Copolyn }\end{array}$ & \multicolumn{3}{|c|}{ (Copolymer) } & 41.9 & 1.75 \\
\hline B- 4 & P(APR-co-NDA) & 1.7 & 38.0 & 49.6 & 1.39 \\
\hline C- 5 & P(DMA co-IPA) & 56.0 & 56.0 & 50.1 & 1.73 \\
\hline D- 6 & P(DMA-co-NHA) & 1.5 & $>100$ & 60.1 & 1.70 \\
\hline D- 7 & P(DMA-co-NHA) & 13.9 & 42.6 & 41.1 & 1.51 \\
\hline E- 8 & P(DMA-co-NOA) & 1.7 & $>100$ & 59.1 & 1.73 \\
\hline E- 9 & P(DMA-co-NOA) & 6.9 & 47.7 & 45.9 & 1.37 \\
\hline F-10 & P(DMA-co-NDA) & 1.9 & $>100$ & 51.9 & 1.53 \\
\hline F-11 & P(DMA-co-NDA) & 2.8 & $>100$ & 48.2 & 1.38 \\
\hline F-12 & P(DMA-co-NDA) & 4.4 & 46.8 & 45.6 & 1.35 \\
\hline
\end{tabular}

a) Prepared with AIBN (1.0 mol \%) in dioxane at $60^{\circ} \mathrm{C}$. b) Determined by ' $\mathrm{H}$ NMR. c) For polymer solution of $0.1 \mathrm{~g} / \mathrm{dL}$. ${ }^{\text {d) }}$ For polymer solution of $0.1 \mathrm{~g} / \mathrm{dL}$ at $25^{\circ} \mathrm{C}$. ${ }^{\text {e) }}$ Intensity ratio of pyrene fluorescence at $374 \mathrm{~nm}$ and 384 $\mathrm{nm}$ in polymer solution of $0.1 \mathrm{~g} / \mathrm{dL}$ at $25^{\circ} \mathrm{C}$.

囲内では悬り点を示さない親水性の高いポリマーである のに対し，PAPR およびPIPA はそれぞれ 53ㅇ および $34^{\circ} \mathrm{C}$ に最り点を示し, PIPAがこれらのポリマーの中で は最す瑓水性が高いポリマーである.これらのポリマー の水溶液の表面張力は親水性の最も高い PDMA が 62.8 $\mathrm{mN} / \mathrm{m}$ であるのに対し, PAPR は $58.5 \mathrm{mN} / \mathrm{m}$, PIPA は $41.9 \mathrm{mN} / \mathrm{m}$ で, ポリマーの疎水性の増大とともに界面 活性が高くなっている. また, ピレンの蛍光強度比, $I_{1} / I_{3}$ 值は親水性ポリマーのPDMA 6最も疎水性が高い PIPA あ 1.72 以上であり，ここで用いたホモポリマーは 蹯水ドメインを形成していないと考えられる.

一方, コポリマーでは APR と NDAのコポリマーで ある B-4 と DMA と IPA のコポリマーであるC-5およ び NHA, NOA, NDA とのコポリマーのうち疎水性のコ モノマー単位の含有量の高い D-7, E-9, F-12 が $0^{\circ} \mathrm{C}$ か ら $100^{\circ} \mathrm{C}$ の範囲内で眎り点を示す。そして, これらの ポリマーはそれぞれ量り点を示さない親水性の高いコポ リマーよりあ低い表面張力を示している. また，それぞ れのコポリマーにおいてあ疎水性の增大ととあに界面活 性が高くなる傾向がある.

コポリマーの $I_{1} / I_{3}$ 值を $\mathrm{M}_{2}$ モノマー単位の含有量で 比較した場合, すべてのコポリマーにおいて $\mathbf{M}_{2} モ$, マー単位の割合が多く，低い表面張力を示すポリマーほ ど $I_{1} / I_{3}$ 值が低くなる傾向がある.これらのコポリマー はコモノマー単位のアルキル銷が疎水相互作用により分 子内会合した疎水ドメインを形成していると思われる. 一方, DMA と NHA およびNOAのコポリマーの中で

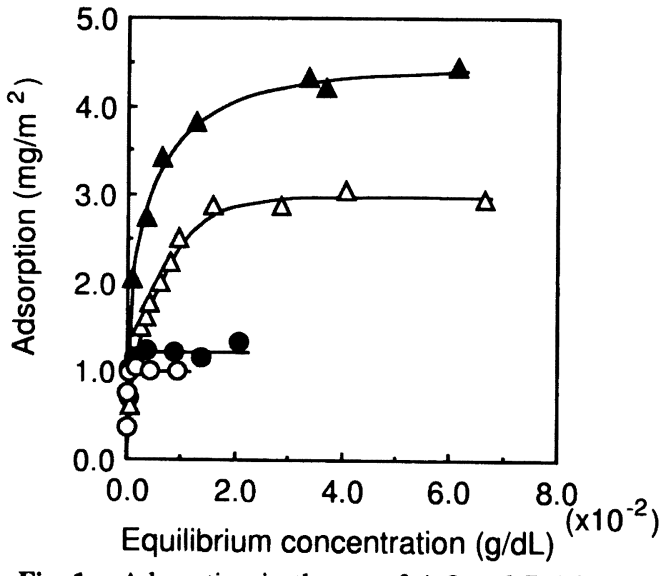

Fig. 1. Adsorption isotherms of A-2 and B-4 in the absence and presence of $\mathrm{AlBr}_{3} . \mathrm{O}, \mathbf{A}-2 ; \mathbf{O}, \mathbf{A}-2+$ $\left[\mathrm{AlBr}_{3}\right]\left(3 \times 10^{-3} \mathrm{~mol} / \mathrm{L}\right) ; \triangle, \mathrm{B}-4 ; \mathbf{A}, \mathrm{B}-4+\left[\mathrm{AlBr}_{3}\right]$ $\left(3 \times 10^{-3} \mathrm{~mol} / \mathrm{L}\right)$.

蹯水性のコモノマー単位の含有量が少ない D-6 と E-8, および DMA と IPA のコポリマーである C-5 は 1.70 以 上の高い $I_{1} / I_{3}$ 値を示し, 疎水ドメインを形成していな いと考えられる。

これらのポリマーは Fig. 1 に示したようにPSラテッ クスに対してポリマーの平衡浱度の增加に伴い吸着量が 飽和する Langmuir 型の吸着特性を示した. Langmuir 型の吸着等温式は (1) 式で示される ${ }^{23)}$ :

$$
1 / W=1 / W_{\mathrm{s}}+\left(1 / a W_{1}\right)(1 / C)
$$


ここで,Wは吸着量, $W$ 。は飽和吸着量, $C$ は平衡濃度 で, それぞれ単位を吸着量は $\mathrm{mg} / \mathrm{m}^{2}$, 平衡浱度は $\mathrm{g} / \mathrm{dL}$ とすると, 吸着の平衡定数 $(a)$ の単位は $\mathrm{dL} / \mathrm{g}$ となる. $a$ 値は吸着が飽和するまでの平衡濃度における吸着等温 線の傾きと関係があり, $a$ 值が大きいことは傾きが大き

Table 2. Amount of adsorption at saturation $\left(W_{0}\right)$ and equilibrium constant $(a)$ for adsorption of polyacrylamides onto PS latexes at $25^{\circ} \mathrm{C}^{\text {) }}$

\begin{tabular}{ccc}
\hline \hline $\begin{array}{c}\text { Code } \\
\text { no. }\end{array}$ & $\begin{array}{c}W, \\
\left(\mathrm{mg} / \mathrm{m}^{2}\right)\end{array}$ & $\begin{array}{c}a \\
\left(10^{2} \mathrm{dL} / \mathrm{g}\right)\end{array}$ \\
\hline $\begin{array}{c}\text { (Homopolymer) } \\
\text { A- 1 }\end{array}$ & 0.80 & 336 \\
A- 2 & 1.03 & 696 \\
A- 3 & 1.05 & 695 \\
(Copolymer) & & \\
B- 4 & 2.96 & 3.51 \\
C- 5 & 1.19 & 59.0 \\
D- 6 & 1.96 & 10.9 \\
D- 7 & 2.92 & 3.51 \\
E- 8 & 2.67 & 6.88 \\
E- 9 & 3.13 & 2.30 \\
F-10 & 2.77 & 5.95 \\
F-11 & 2.87 & 2.45 \\
F-12 & 3.12 & 1.50 \\
\hline
\end{tabular}

a) Langmuir equation: $1 / W=1 / W_{0}+\left(1 / a W_{0}\right)(1 / C)$. $W$, amount of adsorption in $\mathrm{mg} / \mathrm{m}^{2} ; W_{\mathrm{v}}$, amount of adsorption at saturation in $\mathrm{mg} / \mathrm{m}^{2} ; C$, equilibrium concentration of polymer in $10^{-2} \mathrm{~g} / \mathrm{dL} ; a$, equilibrium constant of adsorption in $10^{2} \mathrm{dL} / \mathrm{g}$. いことを示している，そして，a 值はポリマーと PS ラ テックスの相互作用を表している24). 吸着等温線から (1) 式を用いて求めた $W$, と $a$ 值を Table 2 に示した.

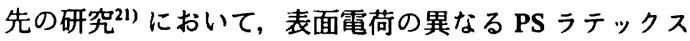
に対するアルキル鎖の長さの異なる $N$-アルキル置換ア クリルアミド系ポリマーの吸着特性について検討した結 果から,ポリマーのPS ラテックスへの吸着は主に柾水 相互作用によって支配され，水溶液中でのポリマー鎖の 溶存状態が吸着の $a$ 值と飽和吸着量に関係することを報 告した. Table 2 において, ホモポリマーでは $a$ 值が高 く，飽和吸着量は低い值を示している。ここでホモポリ マーは先に述べたように疎水ドメインを形成していな い.したがって，ポリマー銷は比較的広がった形態を とっているため, 強い蹯水相互作用を発現し, $a$ 値が高 くなると考えられる.また，これらのホモポリマーは広 がった状態で吸着するため，吸着におけるポリマー鎖の 占有面積が大きく，その結果飽和吸着量が低くなると思 われる.

一方, 各コポリマーの吸着では, コモノマー単位のア ルキル鎖の炭素数および含有量が增大するに従い $a$ 值は 低下し, 飽和吸着量は增加する傾向がある. 特に, アル キル鎖の炭素数が 6 以上の NHA, NOA, NDA とのコポ リマーでは $a$ 值が低く、飽和吸着量が高い值を示してい る. 蹯水性のコモノマー単位を含有するこれらのコポリ マーでは疎水基間の相互作用によってポリマー鎖が収縮 した形態となっているため, ポリマー鎖と PS ラテック 間の疎水相互作用が低くなると共に, 飽和吸着量が大 きくなると考えられる。

Table 3. Cloud point (C.P.) of poly( $N$-alkyl substituted acrylamide)s in the absence and presence of electrolyted

\begin{tabular}{ccccc}
\hline \hline \multirow{2}{*}{$\begin{array}{c}\text { Code } \\
\text { no. }\end{array}$} & $\begin{array}{c}\text { C.P. in the absence } \\
\left.\text { of electrolyte }\left({ }^{\circ} \mathrm{C}\right)^{\mathrm{a}}\right)\end{array}$ & \multicolumn{3}{c}{$\begin{array}{c}\text { C.P. in the presence } \\
\left.\text { of electrolyte }\left({ }^{\circ} \mathrm{C}\right)^{\mathrm{b}}\right)\end{array}$} \\
\cline { 3 - 5 } & & $\mathrm{NaBr}$ & $\mathrm{MgBr}_{2}$ & $\mathrm{AlBr}_{3}$ \\
\hline $\begin{array}{c}\text { (Homopolymer) } \\
\text { A- 1 }\end{array}$ & 100 & $>100$ & $>100$ & $>100$ \\
A- 2 & 53.0 & 53.0 & 66.7 & 74.9 \\
A- 3 & 34.0 & n.d. & n.d. & 29.3 \\
(Copolymer) & 38.0 & & & \\
B- 4 & 56.0 & 40.5 & 53.2 & 57.5 \\
C- 5 & $>100$ & n.d. & n.d. & 65.5 \\
D- 6 & 42.6 & $>100$ & $>100$ & $>100$ \\
D. 7 & $>100$ & n.d. & n.d. & 63.8 \\
E- 8 & 47.7 & $>100$ & $>100$ & $>100$ \\
E- 9 & $>100$ & n.d. & n.d. & 77.9 \\
F-10 & $>100$ & $>100$ & $>100$ & $>100$ \\
F-11 & 46.8 & $>100$ & $>100$ & $>100$ \\
F-12 & n.d. & n.d. & 82.0 \\
\hline
\end{tabular}

a) For polymer solution of $0.1 \mathrm{~g} / \mathrm{dL}$. b) For polymer solution of $0.1 \mathrm{~g} / \mathrm{dL}$; [electrolyte] $=1.0 \mathrm{~mol} / \mathrm{L}$. 


\section{2 り点の国解梊依存性}

Table 3 には臭化ナトリゥム, 臭化マグネシゥム, 臭 化アルミニウムを $1.0 \mathrm{~mol} / \mathrm{L}$ 添加したときの各ポリマー 水溶液の量り点の変化を示した. PAPR 水溶液の悬り 点, および臭化ナトリウム存在下での㟟り点は共に $53.0^{\circ} \mathrm{C}$ で, 毘り点に変化がないのに対し, 臭化マグネ シゥム, 臭化アルミニゥムを添加した系では晨り点がそ れぞれ $66.7^{\circ} \mathrm{C}, 74.9^{\circ} \mathrm{C}$ に高くなっている. また，B-4の ポリマー水溶液の場合もPAPR と同样に臭化マグネシ ウム, 臭化アルミニウムを添加した系では悬り点が高く なっている. 本研究で使用したポリマーの水溶液に臭化 アルミニゥムを添加した場合, PIPA の㬝り点が $34.0^{\circ} \mathrm{C}$ から $29.3^{\circ} \mathrm{C}$ に低下した以外，ほとんどのポリマーの是 り点は高くなっており,ポリマーが親水化していること を示している.

ポリマー水溶液の量り点に対する電解質の添加効果に ついては Saito がビニルアルコールと酢酸ビニルの共重 合体に関して ${ }^{25)}$, Florin らがポリエチレンオキサイドに 関して ${ }^{26)}$, Guner らがポリビニルピロリドンの水溶液に 関して ${ }^{27)}$ 検討している。この中で Saito ${ }^{25)}$ はポリマー水 溶液の量り点の変化を, 電解質の添加によってポリマー の親水基に水和している水の脱水和によりポリマーの親 水性が低下する塩析効果とポリマーの親水性が高くなる 塩溶効果で説明している。

本研究においてPIPA のみが臭化アルミニウムの添加 により悬り点が低下し，㻋水性が高くなっている，これ はアミド基の窒素の置換基の数が 1 置換の PIPA と 2 置 換のPDMA およびPAPR で異なることから，窒素の置 換基の数がアミド基に水和している水に対する電解質の 添加効果に影響しているものと思われるが，詳細につい ては他の電解質を含めて検討中である.

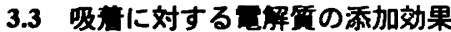

Fig. 1 には臭化アルミニウム存在下での PAPR (A-2) と P(APR-co-NDA) $(\mathrm{NDA}=1.7 \mathrm{~mol} \%)(\mathrm{B}-4)$ のコポリ マーの吸着等温線を示した. 両ポリマーとも電解質を添 加した場合は添加していない場合に比べ飽和吸着量が高 くなっている. 臭化アルミニウム存在下での A-2 と B-4 の $a$ 値を Langmuir の式を用いて求めた. A-2 の $a$ 値は $\mathrm{AlBr}_{3}$ 不在下では 696 であるの対し $\mathrm{AlBr}_{3}$ 存在下では 544, B-4 の $a$ 值は $\mathrm{AlBr}_{3}$ 不在下では 3.51 であるのに対 し $\mathrm{AlBr}_{3}$ 存在下では 4.24 となり, 両ポリマーとも $a$ 値 には大きな差はみられなかった，Tardrosらはアニオン 性PS ラテックスに対するポリビニルアルコールの吸着 において電解質を添加すると吸着量が増大することを示 している，そして，この要因としてPSラテックス表面 の電気二重層が圧縮されることやポリマーの疎水性が大 きくなり，媒体である水に対する溶解性が低下すること を挙げている”．本研究の結果も同様の効果によること

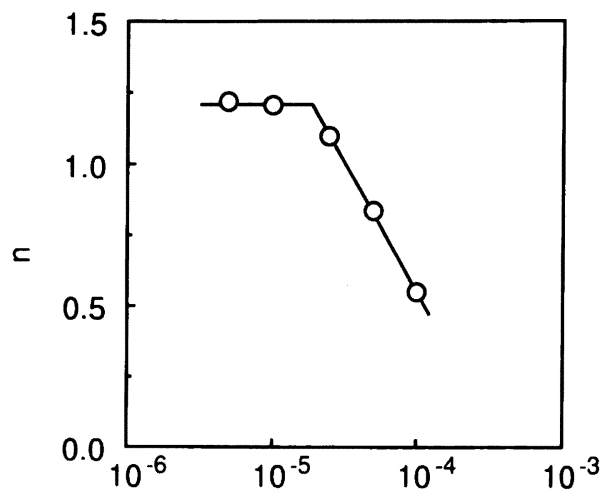

Latex concentration (volume fraction)

Fig. 2. $n$ value versus concentration of PS latex dispersion.

が考えられる. しかし，Table 3 に示したように, A-2 および B-4では臭化アルミニウムが存在するとポリマー の是り点が高くなり蹯水性が隇少する傾向がある。この ことから，本系における臭化アルミニウム存在下での飽 和吸着量の増加は, PS ラテックス表面の有効電荷が低 下し，その表面の疎水性が増加したためであると思われ る.

\section{4 分散安定化効果}

PS ラテックス溶液に臭化アルミニゥムを添加すると ラテックス溶液は疑集を起こす。しかし，PS ラテック ス溶液に Table 1 に示したポリマーを添加すると臭化了 ルミニウムの存在下であラテックス溶液は凝集を起こさ ず安定である.このようなポリマーの安定化効果を電解 質の臨界凝集濃度 $(\mathrm{cfc})$ で評価した。

Fig. 2 にはPS ラテックス水溶液の濃度と $n$ 值 $(=\mathrm{d}$ $\log A / \mathrm{d} \log \lambda)$ の関係を示した. $n$ 值は粒径の関数であ ることが示されており，粒子の凝集が起こると平均粒子 径が増大し, $\boldsymbol{n}$ 值が減少する。これによって $\boldsymbol{n}$ 值から cfc を求めることができる22). 本研究で使用したPS ラ テックスは体積分率が $2 \times 10^{-5}$ 以下では一定の $n$ 値を示 すので, cfc の評価は $1 \times 10^{-5}$ の体積分率で行った。 ま た, $n$ 值は cfc 以下で一定值を示し，この濃度以上では 電解質の濃度の增加に伴い減少する.

Fig. 3 にはポリマー不在下でのPS ラテックスとA-2 または B-4を吸着したPS ラテックスの臭化アルミニゥ ム濃度に対する $n$ 値の変化を示した. $n$ 值は $\mathrm{AlBr}_{3}$ 濃度 に対し明確な届曲点を示す。この屈曲点を臨界凝集濃度 (cfc) とした，臭化アルミニゥムを用いた時, $0.3 \mathrm{~mol} / \mathrm{L}$ 以上での濃度では溶解度の関係でその水溶液に若干の濁 りが生じるため，この濃度以上の cfc 值を求めることは できなかった。 ポリマー不在下での PS ラテックス粒子 


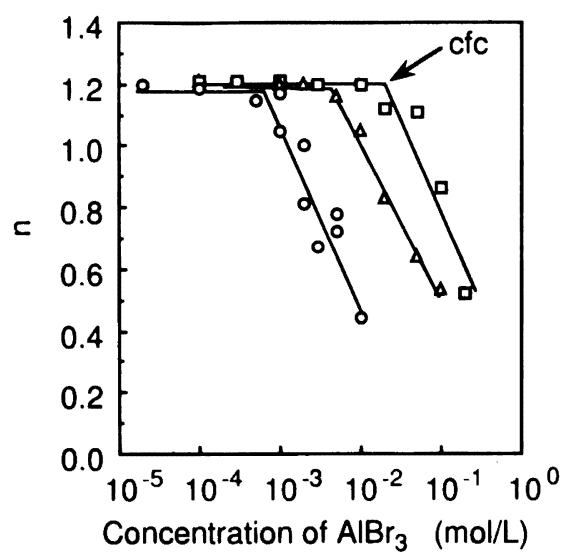

Fig. 3. Critical flocculation concentration (cfc) of $\mathrm{AlBr}_{3}$ for PS latex dispersion in the absence and presence of polyacrylamides at $25^{\circ} \mathrm{C}$. Polymer concentration: $5 \times 10^{-5} \mathrm{~g} / \mathrm{dL}$. $O$, none; $\triangle, A-2 ; \square$, B-4.

Table 4. Critical flocculation concentration (cfc) of $\mathrm{AlBr}_{3}$ for $\mathrm{PS}$ latex dispersion at $25^{\circ} \mathrm{C}^{\text {a) }}$

\begin{tabular}{lccc}
\hline & \multicolumn{3}{c}{ cfc $(\mathrm{mol} / \mathrm{L})$} \\
\cline { 2 - 4 } Polymer & \multicolumn{3}{c}{ Electrolyte } \\
\cline { 2 - 4 } & $\mathrm{NaBr}$ & $\mathrm{MgBr}_{2}$ & $\mathrm{AlBr}_{3}$ \\
\cline { 2 - 4 } None & $1.2 \times 10^{-2}$ & $9.8 \times 10^{-4}$ & $5.1 \times 10^{-4}$ \\
A-2 & $8.7 \times 10^{-2}$ & $5.5 \times 10^{-3}$ & $3.1 \times 10^{-3}$ \\
B-4 & $>2.5$ & $5.6 \times 10^{-2}$ & $2.1 \times 10^{-2}$ \\
\hline
\end{tabular}

a) Particle volume fraction, $1.0 \times 10^{-5}$; polymer concentration, $5.0 \times 10^{-5} \mathrm{~g} / \mathrm{dL}$; time, $20 \mathrm{~h}$.

は比较的低い臭化アルミニウム濃度で cfc を示すのに対 し、ポリマーを吸着したPSラテックスはより高い臭化 アルミニウム浱度で cfcを示している。そして, cfc は A-2よりB-4のポリマーが存在する方が高くなってい ろ.

Table 4 にはA-2 とB-4のポリマーを $5.0 \times 10^{-5} \mathrm{~g} / \mathrm{dL}$ 添加した時の臭化ナトリウム, 臭化マグネシウム, 臭化 アルミニゥムの cfc を示した. しかし，臭化ナトリウム の場合 $2.5 \mathrm{~mol} / \mathrm{L}$ 以上の洤度では水溶液に濁りが生じる ため cfc の測定はできなかった，すべての電解質でポリ マー不在下のPS ラテックスのcfeに対し，ポリマーを 添加したPS ラテックスの cfc は高くなっており, ポリ マーがPS ラテックスに対して分散安定化効果を発現し ていること示している. さらに, cfc 值はすべての電解 質で A-2 より B-4の方が大きくなっている. cfc 值を添 加した電解質の陽イオンで比较するとナトリウム>マグ ネシゥム>アルミニゥムの順に低くなり, 臭化アルミニ
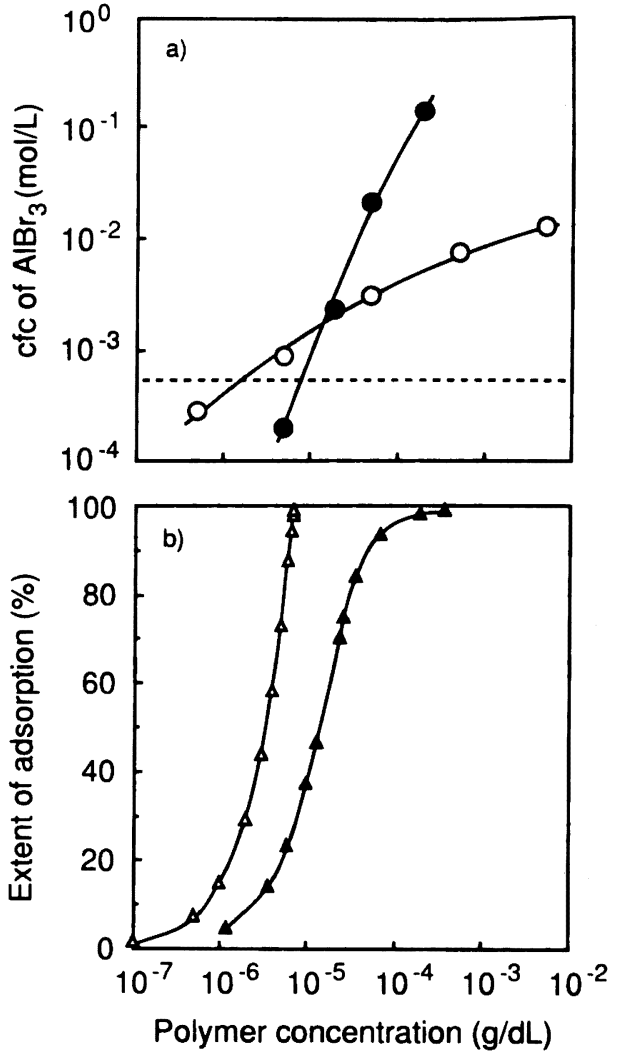

Fig. 4. (a) Dependence of cfc of $\mathrm{AlBr}_{3}$ on polymer concentration at $25^{\circ} \mathrm{C}$ for PS latex dispersion. (b) Calculated adsorption isotherms of polymers. $\bigcirc$ and $\triangle, \mathbf{A}-2 ; 0$ and $\Delta, \mathbf{B}-4$. Extent of adsorption is expressed as the relative amount of adsorption to that at saturation. Broken line refers to cfc for PS latex dispersion in the absence of polymers.

ウムを用いたときの cfc 値が最も低くなっている.

Fig. 4(a)にはA-2 とB-4のポリマーに関して, ポリ マー濃度と cfc 值との関係を示した. A-2 またはB-4 の ポリマー存在下での臭化アルミニゥムの cfc 值は両ポリ マーとすポリマー濃度の增大に伴い增加する傾向があ

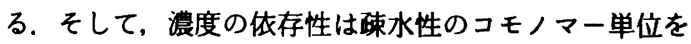
含有するB-4の方が大きくなっている.

Fig. 4(b) には吸着等温線をるとに Langmuir の式 (1) 加計算によって求めた電解質を添加していないときの 飽和吸着量に対するポリマーの吸着量を吸着率として, そのポリマー濃度依存性を示した，B-4 は $1 \times 10^{-6}$ から $1 \times 10^{-4} \mathrm{~g} / \mathrm{dL}$ の間で吸着量が增加している。したがっ て, cfc の增加は吸着量の増加によることも考えられ る. しかし, A-2 は $1 \times 10^{-6} \mathrm{~g} / \mathrm{dL}$ の低濃度で吸着量が 
Table 5. Critical flocculation concentration (cfc) of $\mathrm{AlBr}_{3}$ for $\mathrm{PS}$ latex dispersion at $25^{\circ} \mathrm{C}^{\text {) }}$

\begin{tabular}{lccc}
\hline & \multicolumn{3}{c}{ cfc (mol/L) } \\
\cline { 2 - 4 } Polymer & \multicolumn{3}{c}{ Polymer concn. (g/dL) } \\
\cline { 2 - 4 } & $2 \times 10^{-5}$ & $5 \times 10^{-5}$ & $5 \times 10^{-4}$ \\
\hline None & n.d. & n.d. & $5.1 \times 10^{-4}$ \\
PEO & n.d. & n.d. & $5.5 \times 10^{-4}$ \\
PVP) & n.d. & n.d. & $3.2 \times 10^{-3}$ \\
A- 1 & n.d. & n.d. & $8.9 \times 10^{-3}$ \\
A- 2 & n.d. & $3.1 \times 10^{-3}$ & $7.6 \times 10^{-3}$ \\
A- 3 & n.d. & n.d. & $11.2 \times 10^{-3}$ \\
B- 4 & $2.3 \times 10^{-3}$ & $2.1 \times 10^{-2}$ & $>3.0 \times 10^{-1}$ \\
C- 5 & n.d. & n.d. & $7.2 \times 10^{-3}$ \\
D- 6 & n.d. & $6.9 \times 10^{-3}$ & $>3.0 \times 10^{-1}$ \\
D- 7 & n.d. & $3.7 \times 10^{-2}$ & $>3.0 \times 10^{-1}$ \\
E- 8 & n.d. & $3.5 \times 10^{-2}$ & $>3.0 \times 10^{-1}$ \\
E- 9 & n.d. & $9.3 \times 10^{-2}$ & $>3.0 \times 10^{-1}$ \\
F-10 & $1.1 \times 10^{-2}$ & $1.3 \times 10^{-1}$ & $>3.0 \times 10^{-1}$ \\
F-11 & $2.1 \times 10^{-2}$ & $1.7 \times 10^{-1}$ & $>3.0 \times 10^{-1}$ \\
F-12 & $1.1 \times 10^{-2}$ & $1.7 \times 10^{-1}$ & $>3.0 \times 10^{-1}$ \\
\hline
\end{tabular}

.) Particle volume fraction, $1.0 \times 10^{-5}$; time, $20 \mathrm{~h}$.

b) Poly(ethylene oxide); $M_{w}, 2.0 \times 10^{4}$; surface tension, $61.5 \mathrm{mN} / \mathrm{m}$. c) Poly $\left(N\right.$-vinylpyrrolidone); $M_{w}, 4.0 \times$ $10^{4}$; surfacetension, $64.9 \mathrm{mN} / \mathrm{m}$.

飽和し, 盷和吸着量以上でも cfcが増加している。ポリ マーの吸着量と cfc との関係については古澤らがヒドロ キシプロピルセルロースのPS ラテックスに対する分散 安定化効果について, 飽和吸着量以上のポリマー濃度で は cfc が一定値を示すことを報告している゙). 一方,

Fig. 4(b) でみられる飽和吸着量以上での cfc の增加は, ・先に述べたように臭化アルミニゥム存在下で飽和吸着量 が增加することと, その添加量の增大に伴って吸着量が 增加するためであると考えられる. Fig. 4(a) において, ポリマー浱度が低い時 cfc 值が点線で示したポリマー不 在下でのPS ラテックスの cfc 值よりも低くなっており, ポリマーが疑集作用を発現していることを示している.

これは Ash') らが示しているように複数の粒子にポリ マーが吸着し, 粒子間を橋かけすることにより疑集を起 こすすのと思われる。

Table 5 には各ポリマーを吸着したPS ラテックスの 臭化アルミニゥムに対する cfc を示した. ポリマー不在 下での PS ラテックスの cfc は $5.1 \times 10^{-4} \mathrm{~mol} / \mathrm{L}$ である. ポリマーを $5 \times 10^{-4} \mathrm{~g} / \mathrm{dL}$ 添加した系で比較するとポリ エチレンオキサイド(PEO) を添加した場合の cfc は 5.5

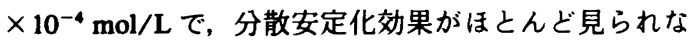
かった. 一方, ポリ $N$-ビニルピロリドン (PVP) を添加 した場合の cfc は $3.2 \times 10^{-3} \mathrm{~mol} / \mathrm{L} て ゙, \mathrm{cfc}$ が高くなって
おり分散安定化効果がみられる。これに対しアクリルア ミド系ポリマーの場合は最も低い cfc 值を示すC-5 のコ

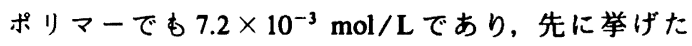
PEO, PVP よりも高い分散安定化効果を示している. 中 でも Table 2 で高い飽和吸着量を示すアルキル基の長さ が 6 以上の NHA, NOA, NDA などのコモノマー単位を 含有するコポリマーでは cfc 值が本実験下では測定不可 能な $0.3 \mathrm{~mol} / \mathrm{L}$ 以上であり, 非常に高い分散安定化効果 がみられる.ポリマーを $5 \times 10^{-5} \mathrm{~g} / \mathrm{dL}$ 添加した系では NHA, NOA の両コモノマー単位を含有するコポリマー では, コモノマー単位の含有量が高いコポリマーの方が 高いcfc 值を示している.これらのコポリマーにおいて あ飽和吸着量の增加とともに分散安定化効果が高くなる 傾向があることを示している．これは電解質を添加する と飽和吸着量が増加し, 飽和吸着量が高いラテックスは 分散安定性が高いためであると思われる.このように, 本実験範囲内ではアクリルアミド系ポリマーであアルキ 儿鎖の長いコモノマー単位でポリマーの一部を疎水化す ることにより PS ラテックスの電解質に対する高い分散 安定化作用を示すことがわかった。

\section{4 桔就}

$N$-アルキル置換アクリルアミド系ポリマーの水溶液 系の特性と PS ラテックスへの吸着特性, およびこれら の特性と PS ラテックスの分散安定性に対する電解質の 影響を調へた。 1 置換型のアミド基を有する PIPA 水溶 液は臭化アルミニウムを添加すると量り点が低くなった が， 2 置換型の DMA および APR の含有量が多いポリ マー水溶液では晨り点が高くなった．PSラテックスに 対するポリマーの吸着量も臭化アルミニウムを添加する と増大した。 アクリルアミド系ポリマーは親水性が高く 飽和吸着量が最も低いPDMAでも水中でのPSラテッ クスの電解質に対する分散安定化効果を示し, 他の親水 性ポリマーである PEOやPVP より高い分散安定化効果 を示した。 また，PDMAに蹯水性の高いモ/マー単位 を導入すると高い分散安定化効果を示すことが分かっ た．ポリマーはその添加量が非常に低い場合には凝集作 用を示したが，ポリマー浱度の增加に伴い cfc が增加し 安定化効果が高くなった，分散安定化効果に対するポリ マー濃度依存性はホモポリマーよりも疎水性のコモ， マー単位を含有するコポリマーの方が大きいことが分 かった．また，高い飽和吸着量を示すポリマーほど高い 分散安定化効果を示す傾向が認められた.

付 钎 PSラテックスの界面電位を測定していただいた内田 充氏に感謝します. 


\section{文献}

1) 高橋 彰, 色材, 67, 496 (1994).

2) 景山洋行, 小林敏勝, 池田承治, 色材, 64, 572 (1991).

3) 景山洋行, 小林敏勝, 池田承治, 日本レオロジー学会誌, 21, 23 (1993).

4) P.-L. Kuo, T.-C. Chang, and L.-M. Lu, J. Appl. Polym. Sci. 44, 859 (1992).

5) P.-L. Kuo and T.-C. Chang, J. Appl. Polym. Sci., 44, 869 (1992).

6) K. Furusawa and T. Tagawa, Colloid Polym. Sci., 263, 353 (1985).

7) Th. F. Tadros and B. Vincent, J. Colloid Interface Sci., 72, 505 (1979).

8) T. Cosgrove, T. L. Crowley, K. Ryan, and J. R. P. Webster, Colloids Surf., 51, 255 (1990).

9) S. G. Ash and E. J. Clayfield, J. Colloid Interface Sci., 55, 645 (1976).

10) B. Vincent, P. F. Luckham, and F. A. Waite, J. Colloid Interface Sci., 73, 508 (1980).

11) M. Kawaguchi, I. Hayashi, and A. Takahashi, Polym. J., 13, 783 (1981).

12）川口正美, 近藤郁男, 高橋 彰, 高分子論文集, 37, 427 (1980).

13) M. Puterman and R. M. Fitch, J. Appl. Polym. Sci., 40, 333 (1990).

14) C. Cowell and B. Vincent, J. Colloid Interface Sci., 95, 573 (1983).
15) M. B. Einarson and J. C. Berg, J. Colloid Interface Sci., 155, 165 (1993).

16) K. Furusawa, H. Sakai, N. Watanabe, and N. Tomotsu, Bull. Chem. Soc. Jpn., 56, 997 (1983).

17) T. Tanahashi, M. Kawaguchi, T. Honda, and A. Takahasi, Macromolecules, 27, 606 (1994).

18) F. M. Winnik, A. R. Davidson, G. K. Hamer, and H. Kitano, Macromolecules, 25, 1876 (1992).

19) H. Ringsdorf, J. Venzmer, and F. M. Winnik, Macromolecules, 24, 1678 (1991).

20) H. Ringsdorf, J. Simon, and F. M. Winnik, "ColloidPolymer Interactions: Particulate, Amphiphilic, and Biological Surfaces", P. L. Dubin and P. Tong, Ed., Symposium Series, No. 532, The American Chemical Society, Washington, D.C. (1993), p. 216.

21）浅田啓介, 城戸淳二, 倉本蘘幸, 長井勝利, 高分子論文 集, 印刷中.

22) J. A. Long, D. W. J. Osmond, and B. Vincent, J. Colloid Interface Sci., 42, 545 (1973).

23) M. J. Rosen, "Surfactants and Interfacial Phenomena", Wiley, New York (1978), p. 36.

24) 近藤精一, 石川達雄, 安部郁夫, “吸着の科学”, 丸善, 東京 (1991), p. 35.

25) S. Saito, J. Polym. Sci., A-1, 7, 1789 (1969).

26) B. Y. Florin, R. Kjellander, and J. C. Eriksson, J. Chem. Soc., Faraday Trans. 1, 80, 2889 (1984).

27) A. Guner and M. Ataman, Colloid Polym. Sci., 272, 175 (1994).

Stabilization of Anionic Polystyrene Latex Dispersion by Poly( $N$-alkylsubstituted acrylamide)s in Aqueous Media

Keisuke ASADA*1, Junji KIDo*1, Noriyuki KuRAmoto*1, and Katsutoshi NAGAI*1

*1Department of Materials Science and Engineering, Faculty of Engineering, Yamagata University (4-3-16, Jonan, Yonezawa, Yamagata, 992 Japan)

The effect of poly ( $N$-substituted acrylamide)s on the dispersion stability of anionic polystyrene (PS) latexes estimated from critical flocculation concentration (cfc) of electrolytes was investigated. All of polyacrylamides used in this work stabilized the dispersion in the presence of electrolytes. The effect was displayed even by poly $(N, N$ dimethylacrylamide) which has a high hydrophilicity, and it became much higher for the polymers involving monomer units with a high hydrophobicity. The stability increased with increasing polymer concentration. The concentration dependence was stronger for copolymers involving monomer units with a long alkyl chain than for homopolymers. The stabilization effect was found to be closely related to the amount of adsorption of polymers onto PS latexes.

KEY WORDS Poly( $N$-substituted acrylamide)s / Polystyrene Latex / Adsorption / Electrolyte /

Critical Flocculation Concentration /

(Received April 6, 1995: Accepted June 26, 1995) [Kobunshi Ronbunshu, 52(9), 559-566 (1995)] 